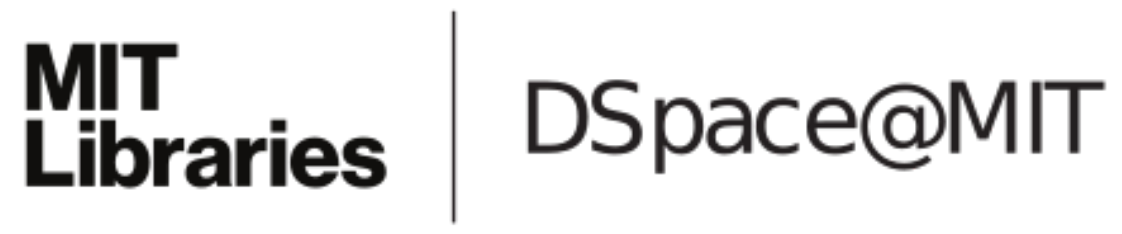

\author{
MIT Open Access Articles
}

New synthetic strategies for the stereocontrolled synthesis of substituted 'skipped' diepoxides

The MIT Faculty has made this article openly available. Please share how this access benefits you. Your story matters.

Citation: Morten, Christopher J., and Timothy F. Jamison. "New Synthetic Strategies for the Stereocontrolled Synthesis of Substituted 'skipped' Diepoxides." Tetrahedron 65, no. 33 (August 2009): 6648-6655.

As Published: http://dx.doi.org/10.1016/j.tet.2009.05.074

Publisher: Elsevier

Persistent URL: http://hdl.handle.net/1721.1/99512

Version: Author's final manuscript: final author's manuscript post peer review, without publisher's formatting or copy editing

Terms of use: Creative Commons Attribution-Noncommercial-NoDerivatives 


\title{
New synthetic strategies for the stereocontrolled synthesis of substituted "skipped" diepoxides
}

\author{
Christopher J. Morten and Timothy F. Jamison \\ Department of Chemistry, Massachusetts Institute of Technology, 77 Massachusetts Ave., \\ Cambridge, MA 02139, USA
}

\begin{abstract}
This report describes a number of new synthetic approaches towards methyl-substituted mono- and diepoxy alcohols that serve as substrates for endo-selective epoxide-opening cascades. The key transformations involve the manipulation of alkynes. Highlighted are the directed methylmetalation of bishomopropargylic alcohols, the bromoallylation of alkynes, and Pd-catalyzed cross-coupling between an alkenyl boronate ester and allylic bromides.
\end{abstract}

\section{Introduction}

Skipped dienes, also known as 1,4- or homoconjugated dienes, are a key structural motif found in a number of important natural products, including several leukotrienes, the omega-3 fatty acids, insect pheremones, ${ }^{i}$ and the macrolide amphidinolide A, among many others. Skipped polyene structures are also notable for their proposed intermediacy in the biosynthesis of ladder polyether natural products (such as brevetoxin B, 3, Scheme 1).

These natural products, notorious for their acute toxicity and for the environmental destruction they wreak, have long fascinated organic chemists due to their intriguing mixture of structural complexity and stereochemical uniformity. ${ }^{\mathrm{ii}}$ It was Nakanishi who, nearly 25 years ago, advanced a concise proposal for the biosynthesis of brevetoxin B and other ladder polyethers, a synthesis that culminates in a cascade of regio- and stereospecific epoxide openings. ${ }^{\text {iii }}$ The appeal of this hypothesis lies in its economy. In vivo, a single stereoselective epoxidase, chemoselective for $E$ alkenes, acting on polyene 1 could generate all $(R, R)$-"skipped polyepoxide" 2 , which could in turn undergo an all-endo cascade of epoxide-opening cyclizations to afford brevetoxin $\mathrm{B}, 3$. $^{\text {iv }}$

\begin{abstract}
Abbreviated skipped polyenes similar to 1 can be useful substrates for epoxidation and subsequent studies of biomimetic in vitro epoxide-opening cascades. Construction of these polyepoxides requires a protocol that is reliably highly $(R, R)$ - or $(S, S)$-selective for a wide variety of trans-disubstituted and trisubstituted alkenes. The powerful Shi asymmetric epoxidation, ${ }^{\mathrm{V}}$ in which the active catalyst is a chiral dioxirane generated in situ from a simple, fructose-derived ketone, has emerged as just such a method. If asymmetric epoxidations of this
\end{abstract}

\footnotetext{
(c) 2009 Elsevier Ltd. All rights reserved.

Correspondence to: Timothy F. Jamison.

Dedicated to Professor Larry E. Overman on his receipt of the 2008 Tetrahedron Prize and in honor of his many important contributions to organic chemistry.

This is a PDF file of an unedited manuscript that has been accepted for publication. As a service to our customers we are providing this early version of the manuscript. The manuscript will undergo copyediting, typesetting, and review of the resulting proof before it is published in its final citable form. Please note that during the production process errors may be discovered which could affect the content, and all legal disclaimers that apply to the journal pertain.
} 
type are justifiably taken to be something of a "solved problem," the stereocontrolled synthesis of the necessary trans-disubstituted and $E$-trisubstituted alkenes (and polyenes) then becomes the primary challenge.

The difficulty of synthesizing highly substituted alkenes with careful stereo- and regiocontrol is well documented. ${ }^{\text {vi }}$ Furthermore, the construction of skipped dienes can be additionally troublesome due to the rather delicate doubly allylic protons found in these compounds. The $\mathrm{pK}_{\mathrm{a}}$ of 1,4-pentadiene (divinylmethane) in DMSO is approximately 35, vii making doubly allylic protons sensitive to strong base, and the same $\mathrm{C}-\mathrm{H}$ bonds are also susceptible to hydrogen atom abstraction, viii which can lead to subsequent di-П-methane rearrangement.ix Thus the synthesis of skipped dienes and polyenes must generally avoid very strong bases (such as alkyllithiums) and reagents that promote single electron processes.

\subsection{Previous Work}

Strategies for skipped polyenes previously explored in our group targeted the synthesis of trimethylsilyl (TMS)-substituted skipped polyenes ${ }^{\mathrm{x}}$ and all-trans-disubstituted polyenes ${ }^{\mathrm{xi}}$ from bishomopropargylic alcohol 4 (Scheme 2). These polyenes were then transformed into the polyepoxy alcohols 5 and $\mathbf{6}$, respectively, with high diastereoselectivity via Shi epoxidation. Polyepoxy alcohols $\mathbf{5}$ and $\mathbf{6}$ then underwent endo-selective epoxide-opening cascades (accompanied by concomitant protiodesilylation in reactions of 5) to afford THP tetrad $\mathbf{7}$, a characteristic structural subunit of the ladder polyether natural products. ${ }^{10,11}$

Versatile alkyne $\mathbf{4}$ was transformed into the skipped triene precursor to $\mathbf{5}$ via the coppermediated cross-coupling of a propargyl nucleophile and a TMS-substituted alkenyl iodide.

10c The all-trans-disubstituted triene precursor to 6 was obtained from dissolving metal reduction of a skipped triyne. Thus the two quite differently substituted triepoxides $\mathbf{5}$ and $\mathbf{6}$ could both be straightforwardly derived from common intermediate $\mathbf{4}$, and both 5 and $\mathbf{6}$ cyclized to afford tetrad 7.

It is notable that the ring junctions of $\mathbf{7}$ are all hydrogen-substituted. A cursory glance at the ladder polyether natural products reveals that methyl (Me) substituents are also frequently encountered at ring junctions (as in brevetoxin B (3, Scheme 1), which bears Me groups at five of its ten ring junctions). Methyl substituents also appear in $\mathbf{1}$ and 2, Nakanishi's hypothesized polyepoxide and polyene precursors to brevetoxin $\mathrm{B}$. The Me groups that decorate the trisubstituted epoxides of $\mathbf{2}$ are encountered both distal and proximal to the internal nucleophile. ${ }^{\text {iii }}$ This point is critical, as the Me group can exert a rather powerful directing effect on the regioselectivity of epoxide opening, particularly under acidic activation. ${ }^{\text {iii }}$

We recently reported that water overcomes methyl group directing effects in endo-selective epoxide-opening cyclizations to enable the rapid construction of fused tetrahydropyran (THP) bicycles and tricycles with the incorporation of angular Me groups. ${ }^{\mathrm{xiv}}$ In that report we described the effects of Me substitution in epoxide-opening reactions of diversely methylsubstituted mono- and diepoxy alcohols 8-12 (Scheme 3). The key propargylation and dissolving metal reactions used for diene and triene syntheses en route to $\mathbf{5}$ and $\mathbf{6}$ were unfortunately not readily amenable to the controlled incorporation of Me substituents into alkenes and skipped polyenes. We were therefore obligated to develop a number of new synthetic strategies for the synthesis of 8-12. We herein describe these strategies for the stereoand regiocontrolled synthesis of trisubstituted epoxides (and their trisubstituted alkene precursors). Two of the key transformations highlighted in this work, Thompson's directed methylmetalation of alkynes ${ }^{\mathrm{xv}}$ and Kaneda's haloallylation of alkynes, xvi have to our knowledge been rather infrequently used in total synthesis and related applications, but both methods have proved indispensable to our work. Furthermore, all of the syntheses detailed here 
begin from common intermediate 4 . We believe that this work further emphasizes the utility and versatility of alkyne $\mathbf{4}$ as a synthetic platform.

\section{Results and Discussion}

\subsection{Monoepoxide Syntheses}

Bishomopropargylic alcohol 4 is prepared easily on a gram scale in five steps from 2,3dihydropyran. ${ }^{\text {xvii }}$ We began our exploration into new transformations of $\mathbf{4}$ by tackling the synthesis of monoepoxy alcohol $\mathbf{8}$. Compound $\mathbf{8}$ bears a proximal methyl substituent and is therefore Me-substituted at both sides of the epoxide. Consequently, we planned to approach $\mathbf{8}$ via syn-selective 1,2-difunctionalization of alkyne $\mathbf{4}$ (or a protected derivative of $\mathbf{4}$ ).

Repeated attempts at 1,2-difunctionalization of $\mathbf{4}$ and its TBS ether 13 via Negishi carbometalationxviii resulted either in very low or undetectable conversion under standard conditions (2 equiv $\mathrm{AlMe}_{3}$ and 1 equiv $\mathrm{Cp}_{2} \mathrm{ZrCl}_{2}$ in $\mathrm{CH}_{2} \mathrm{Cl}_{2}$ or 1,2-dichloroethane at room temperature) (Scheme 4). Heating above $30^{\circ} \mathrm{C}$ led only to the decomposition of starting material. Attempted methylalumination of $\mathbf{4}$ and $\mathbf{1 3}$ with the stoichiometric addition of water according to the modified protocol of Wipf and Lim ${ }^{\mathrm{xix}}$ likewise led to poor conversion and significant decomposition. Similarly, methylcupration ${ }^{\mathrm{xx}}$ of $\mathbf{1 3}$ was too slow to be practical. Thus the highly beguiling rapid, syn-stereoselective methylmetalation for the eventual 1,2dimethylation of alkynes was unfortunately but a siren's song, leading only to failure in our early studies.

Other attempts at 1,2-difunctionalization of $\mathbf{1 3}$ via silylcupration and stannylcupration ${ }^{\mathrm{xxi}}$ were also unsuccessful, with low conversion observed in all cases and only stannylcupration ${ }^{\mathrm{xxii}}$ yielding even a trace of the desired adduct.

It appeared that $\mathbf{4}$ and $\mathbf{1 3}$ were relatively inert under standard undirected carbometalation and metallometalation conditions. In the case of $\mathbf{1 3}$, the minimal alkyne reactivity may perhaps be due to the steric demand of the neighboring bulky silyl group in the lowest energy conformer of the molecule (alkyne and silyl ether both equatorial).

This inferred proximity could be turned to our advantage, however, in carbometalation directed by the free hydroxyl group in 4 (Scheme 4). Thompson's method for the directed methylmetalation of propargylic, homopropargylic, and bishomopropargylic alcohols with $\mathrm{TiCl}_{4}$ and $\mathrm{AlMe}_{3},{ }^{15}$ recently used in the total synthesis of (-)-borrelidin by the Omura group,xxiii proved highly effective. Methylmetalation of $\mathbf{4}, \mathrm{I}_{2}$ treatment, and subsequent silyl protection afforded alkenyl iodide $\mathbf{1 6}$ in a modest $41 \%$ yield, but with $>20: 1$ regio- and stereoselectivity.

Alkenyl iodide $\mathbf{1 6}$ could be transformed into epoxide-opening cyclization substrate $\mathbf{8}$ in three simple steps via Negishi coupling with dimethylzinc, Shi asymmetric epoxidation (Shi AE), and TBAF-induced deprotection of the TES ether (Scheme 5). The Shi asymmetric epoxidation step proceeded with considerably lower than is typically observed in Shi epoxidations of trisubstituted alkenes. We conjecture that this poor diastereoselectivity arises from a mismatched relationship between the chiral dioxirane epoxidation agent and the stereocenters of the neighboring THP ring. However, as we have not attempted epoxidation with the antipodal ketone catalyst (derived from expensive L-fructose), we cannot confirm this hypothesis.

With epoxy alcohol $\mathbf{8}$ in hand, we turned to the synthesis of its isomer $\mathbf{9}$, an epoxide-opening cyclization substrate that bears a distal Me substituent (located on the far side of the epoxide with respect to the alcohol). This Me group was appended via alkylation of a derivative of 
alkyne 4 with iodomethane to afford bishomopropargylic alcohol 19 (Scheme 6). As the synthetic elaboration of internal alkyne $\mathbf{1 9}$ requires the incorporation of only one additional Me group, we initially attempted to perform a hydrometalation/methylation sequence on $\mathbf{1 9}$ and its silyl-protected derivatives with Schwartz's reagent, DIBAL, or 9-BBN, but observed in all cases low yield, poor regioselectivity, or both.

Instead of hydrometalation, standard Thompson carbometalation conditions (2.2 equiv $\mathrm{AlMe}_{3}$ and 1.1 equiv $\mathrm{TiCl}_{4}$ in $\mathrm{CH}_{2} \mathrm{Cl}_{2}$ at $-78^{\circ}$ ) proved best. Upon quenching with aqueous acid, carbometalation smoothly afforded trisubstituted alkene $\mathbf{2 0}$ in $70 \%$ yield (79\% based on recovered starting material) and with no observable trace of undesired regio- or stereoisomers. Silyl protection, asymmetric epoxidation, and deprotection then provided distally Mesubstituted epoxy alcohol 9.

\subsection{Diepoxide Syntheses}

2.2.1. Synthesis of Diepoxide 10-In general, the alkenylmetal products of carbometalation are highly versatile and thus highly valuable, as they can be functionalized directly in a quenching operation with a variety of simple electrophiles (e.g. $\mathrm{H}^{+}, \mathrm{I}_{2}$, a few highly electrophilic carbon electrophiles) or transmetalated to $\mathrm{Pd}$ or $\mathrm{Cu}$ and subsequently used as nucleophiles in conjugate addition and cross-coupling processes. ${ }^{\text {xxiv }}$ Unfortunately, however, Thompson carbometalation involves delivery of the metal to the proximal end of alkynes 4 and 19 (and Me to the distal end). This regiochemistry precludes using transmetalation of the alkenylmetal and subsequent coupling for the construction of linear skipped dienes or polyenes.

For the assembly of the linear skipped dienes necessary for the synthesis of diepoxy alcohols 10, 11, and 12, the development of new strategies became necessary. While terminal alkynes 4 and 13 were nearly inert to undirected carbometalation with $\mathrm{Cu}$ and $\mathrm{Al} / \mathrm{Zr}$ systems, we elected to try these and closely related substrates in a catalytic halopalladation process. To our delight, halopalladation proved straightforward and efficient.

The palladium-catalyzed haloallylation of alkynes was discovered by Kaneda, Teranishi, and coworkers. ${ }^{16}$ It has seen some use in recent years, with notable extensions of the method reported by the Rawal group ${ }^{\mathrm{xxv}}$ and a synthetic application described by Hoye and coworkers. ${ }^{x x v i}$ It has proved invaluable to our own work. The method effects chloro- and bromoallylation of alkynes via the proposed mechanism shown in Scheme 7. ${ }^{16}$,xxvii The first step is regio- and $s y n$-stereoselective alkyne hallopalladation to afford alkenylpalladium halide 23. After binding and 1,2 insertion of an allylic halide to give $\mathbf{2 4}, \beta$-halide elimination gives diene 25.

Trans-selective halocrotylation of $\mathbf{2 6}$, the TBDPS ether of $\mathbf{4}$, would provide direct access to the synthetically useful skipped diene $\mathbf{2 7}$ (Scheme 8), which bears the appropriate substitution at both the disubstituted and trisubstituted alkenes. This transformation proved problematic in practice. Bromocrotylation is not straightforward, as the requisite 3-bromo-1-butene is not commercially available and isomerizes to crotyl bromide at ambient temperature.xxviii Chlorocrotylation with 3-chloro-1-butene was successful, but the $E$ : $Z$ selectivity was only 1.7:1. Moreover, all attempts to effect the cross-coupling of the isomeric alkenyl chloride products with dimethylzinc via a $\mathrm{Pd} / \mathrm{P}(t \mathrm{Bu})_{3}$ catalyst system ${ }^{\mathrm{xxix}}$ were unsuccessful.

We found more success with simple bromoallylation and subsequent homologation. Bromoallylation of $\mathbf{2 6}$ under conditions slightly modified from the original Kaneda conditions (dropwise addition of the alkyne to a room temperature solution of $5 \mathrm{~mol} \% \mathrm{PdCl}_{2}(\mathrm{PhCN})_{2}$ in allyl bromide, with the addition of 5 equiv of $\mathrm{NaHCO}_{3} \mathrm{xxx}$ ) afforded diene 28 in $88 \%$ yield, with no trace of undesired regio- and stereoisomers (Scheme 9). Methylation of alkenyl 
bromide 28 via Negishi coupling with dimethylzinc and a subsequent Shi asymmetric epoxidation chemoselective for the more electron-rich trisubstituted alkene provided epoxy alkene 29. This monosubstituted alkene was readily and nearly quantitatively converted to the methylated disubstituted alkene via cross metathesis ${ }^{\mathrm{xxxi}}$ with cis-2-butenexxxii using the Hoveyda-Grubbs $2^{\text {nd }}$ generation metathesis catalyst 31 (5 mol\%),xxxiii in respectable 4.1:1 $E: Z$ stereochemical purity. While a simple Me group is added in this reaction, cross metathesis is of course a versatile strategy that also makes possible the appendage of more complex epoxy alkenes for the eventual synthesis of longer epoxide chains.xxxiv Shi epoxidation of the resultant disubstituted alkene afforded the diepoxide in modest (2.7:1) overall $\mathrm{dr}$, but we were able to improve this to better than 20:1 dr via preparative HPLC. The choice of TBDPS as silyl protecting group was in large part due its UV activity, which made detection on HPLC possible. Finally, cleavage of the silyl ether afforded diepoxy alcohol and epoxide-opening cascade substrate $\mathbf{1 0}$.

2.2.2. Synthesis of Diepoxide 11-These results in hand, we were initially hopeful that Kaneda haloallylation could be extended to the synthesis of diepoxy alcohol cascade substrates 11 and 12. Both of these substrates bear a Me substituent on the distal side (the endo site of attack) of the epoxide closer to the THP ring. Unfortunately, bromoallylation of internal alkyne 32 unexpectedly proceeded with a reversal of regioselectivity as compared to that observed with terminal alkyne $\mathbf{2 6}$ such that undesired regioisomer $\mathbf{3 3}$ predominated (Scheme 10).

Ultimately, for the synthesis of diepoxide 11, we took recourse to the hydrometalation/crosscoupling strategy first investigated for the preparation of distally trisubstituted monoepoxide 9. Hydrozirconation of $\mathbf{3 2}$ with $\mathrm{Cp}_{2} \mathrm{Zr}(\mathrm{H}) \mathrm{Cl}$ (Schwartz's reagent) proceeded in good yield, but the regioselectivity of addition across the alkyne was nearly $1: 1$, and separation of the resultant regioisomers after either iodinolysis of the $\mathrm{C}-\mathrm{Zr}$ bond or transmetalation to $\mathrm{Zn}$ and quench with carbon electrophiles proved troublesome.

Uncatalyzed hydroboration of $\mathbf{3 2}$ with pinacolborane was so slow as to be entirely impractical, but the addition of catalytic quantities ( 0.1 equiv) of $\mathrm{Cp}_{2} \mathrm{Zr}(\mathrm{H}) \mathrm{Cl}$ and triethylamine according to the modification of Wang, et al. ${ }^{\mathrm{xxx}}$ to the method developed by Pereira and Srebnikxxxvi improved the reaction rate (Scheme 11). However, even with $\mathrm{Cp}_{2} \mathrm{Zr}(\mathrm{H}) \mathrm{Cl}$ catalysis and upon heating the hydroboration reaction mixture to $60^{\circ}$ for $28 \mathrm{~h}$, conversion of starting alkyne 32 to pinacolates $\mathbf{3 5}$ and $\mathbf{3 6}$ was typically only $60-80 \%$. While less than ideal, we found that these conditions represented a reasonable compromise, as longer reaction times and higher temperatures led to lower mass recovery. While poor conversion is a drawback of this transformation, unreacted $\mathbf{3 2}$ could be recovered and recycled. Furthermore, the stereochemistry of addition was cleanly syn, the regioselectivity was 2.0:1 in favor of the desired $\mathbf{3 5}$ over the undesired $\mathbf{3 6}$, and, most important, the two regioisomeric pinacolate esters were readily separable by column chromatography.

After purification, alkenyl boronate ester 35 was cross-coupled with allyl bromide via Pdcatalyzed conditions adapted from those developed by Miyaura and coworkers.xxxvii The addition of 2 equivalents of water was found to improve the reaction rate substantially, presumably by effecting in situ hydrolysis of the boronate ester to the more reactive boronic acid. Bidentate bisphosphine ligands like dppe and the best ligand identified, dppf, were found to improve reaction rate as compared to those with monodentate ligands such as $\mathrm{PPh}_{3}, \mathrm{PCy}_{3}$, or Buchwald ligands.xxxviii

The crude diene was carried into Shi epoxidation (again chemoselective for the more electronrich trisubstituted olefin over the monosubstituted) to afford epoxy alkene 37. Cross metathesis of 37 with cis-2-butene again proceeded in excellent yield and good stereoselectivity (4.2:1 $E: Z$ ), and the resulting disubstituted alkene was subjected to another Shi epoxidation to afford 
the diepoxide in disappointing 1.5:1 overall $\mathrm{dr}$. The 1.5:1 mixture of diastereomers was enhanced to greater 9:1 diastereopurity via preparative HPLC, and final TBAF deprotection gave diepoxy alcohol and cascade substrate $\mathbf{1 1}$ in excellent yield.

2.2.3. Synthesis of Diepoxide 12-The synthesis of the third and final diepoxy alcohol cascade substrate 12, which bears methyl substituents on both epoxides, intercepted the synthesis of $\mathbf{1 1}$ at alkenyl boronate ester $\mathbf{3 5}$ (Scheme 12). Cross coupling of $\mathbf{3 5}$ with prenyl bromide (rather than allyl) proceeded in similarly good $75 \%$ overall yield, but the coupling, which goes through an unsymmetrical $\pi$-allyl intermediate, resulted in a 2.5:1 mixture of the desired $\mathrm{S}_{\mathrm{N}} 2$ product 39 along with undesired $\mathrm{S}_{\mathrm{N}} 2$ ' product $\mathbf{4 0}$.

These diene isomers were inseparable by column chromatography, but Shi epoxidation proved chemoselective yet again, epoxidizing both trisubstituted alkenes in $\mathbf{3 9}$, but leaving untouched the monosubstituted olefin in $\mathbf{4 0}$ to give a readily separable mixture of monoepoxide $\mathbf{4 1}$ and diepoxide $\mathbf{4 2}$ (65\% yield based on 39, 3.5:1 dr). The diastereopurity of $\mathbf{4 2}$ was improved via preparative HPLC, and samples of $\geq 15: 1 \mathrm{dr}$ were subjected to TBAF deprotection to afford diepoxy alcohol 12.

\section{Conclusion}

We have developed synthetic routes to trisubstituted mono- and diepoxides 8-12, which serve as substrates in endo-selective epoxide-opening cyclizations and cascades. The longest of these routes (the synthesis of 11) is eight steps from known homopropargylic alcohol $\mathbf{4}$. We believe that these transformations highlight the remarkable versatility of common intermediate 4 .

Further exploration into new methods for the stereocontrolled construction of skipped polyenes and epoxide chains is ongoing in our laboratory.

\section{Experimental}

\subsection{General}

Full experimental details for compounds 4, 8-12, 16-17, 19-21, 26, 28-30, 32, 35, 37-38, and 42-43 are available in the Supporting Information to reference ${ }^{14}$.

All air-sensitive reactions were performed under an oxygen-free atmosphere of argon with rigid exclusion of moisture from reagents and glassware. Dichloromethane was either distilled from calcium hydride or purified via an SG Water USA solvent column system.

Tetrahydrofuran (THF) and $\mathrm{Et}_{2} \mathrm{O}$ were either distilled from a blue solution of benzophenone ketyl or purified via an SG Water USA solvent column system. Triethylamine was purified via an SG Water USA solvent column system. Methyl iodide and allyl bromide were purified by filtration through basic alumina before use. $\mathrm{K}_{3} \mathrm{PO}_{4}$ was oven-dried overnight before use. Chiral ketone 18, used in Shi asymmetric epoxidation, was prepared from D-fructose according to the procedure of Vidal-Ferran and coworkers.xxxix All other reagents and solvents were used as obtained, without further purification.

\subsection{Preparation of alkenyl iodide 16 by carbometalation}

To a solution of bishomopropargylic alcohol $4(265 \mathrm{mg}, 1.89 \mathrm{mmol})$ in $\mathrm{CH}_{2} \mathrm{Cl}_{2}(20 \mathrm{~mL})$ at $-78^{\circ}$ was added slowly a $2 \mathrm{M}$ solution of $\mathrm{AlMe}_{3}$ in hexanes $(2.08 \mathrm{~mL}, 4.16 \mathrm{mmol})$. This solution was warmed for $3 \mathrm{~min}$. by removing the flask from its cold bath to ensure complete deprotonation. After recooling to $-78^{\circ}$, a $1 \mathrm{M}$ solution of $\mathrm{TiCl}_{4}$ in $\mathrm{CH}_{2} \mathrm{Cl}_{2}(2.08 \mathrm{~mL}, 2.08$ $\mathrm{mmol}$ ) was added dropwise. The solution was stirred $2 \mathrm{~h}$. at $-78^{\circ}$ and then quenched with a solution of $\mathrm{I}_{2}(2.4 \mathrm{~g}, 9.45 \mathrm{mmol})$ in $\mathrm{Et}_{2} \mathrm{O}(20 \mathrm{~mL})$. The reaction flask was then wrapped in foil and allowed to warm to room temperature for $10 \mathrm{~h}$., at which point $\mathrm{H}_{2} \mathrm{O}(2 \mathrm{~mL})$ was added. The quenched reaction solution was diluted with $\mathrm{Et}_{2} \mathrm{O}(100 \mathrm{~mL})$ and washed with aqueous 3 
$\mathrm{M} \mathrm{NaHSO}_{3}(40 \mathrm{~mL})$ until the organic layer was colorless. The aqueous layer was extracted with $\mathrm{Et}_{2} \mathrm{O}(3 \times 40 \mathrm{~mL})$, and the combined organics were washed with sat. $\mathrm{NaCl}$, dried over $\mathrm{MgSO}_{4}$, and concentrated in vacuo. The crude alkenyl iodide was carried forward without purification; $\mathrm{R}_{\mathrm{f}}=0.72$ (50\% EtOAc in hexanes), UV active.

Upon dissolution of this crude in DMF (1 mL), imidazole (322 $\mathrm{mg}, 4.73 \mathrm{mmol})$ and TESC1 ( $380 \mu \mathrm{L}, 342 \mathrm{mg}, 2.27 \mathrm{mmol}$ ) were added, and the solution was stirred $2 \mathrm{~h}$. at room temperature. The reaction was applied directly to column of $\mathrm{SiO}_{2}$ and chromatographed (2\% EtOAc in hexanes) to afford 16 ( $310 \mathrm{mg}, 0.78 \mathrm{mmol}, 41 \%$ over 2 steps), which was isolated along with some silylated bishomopropargylic alcohol ( $43 \mathrm{mg}, 0.17 \mathrm{mmol}) . \mathbf{R}_{\mathbf{f}}$ of $\mathbf{1 6}=0.60$ (10\% EtOAc in hexanes), $\mathrm{UV}$ active; $[\boldsymbol{\alpha}]^{22} \mathbf{D}=-19.2\left(c=4.0, \mathrm{CHCl}_{3}\right)$.

IR (thin film, NaCl) 2955, 2876, 1461, 1415, 1274, 1239, 1127, 1102, $1004 \mathrm{~cm}^{-1}$

${ }^{1} \mathbf{H}$ NMR $\left(500 \mathrm{MHz}, \mathrm{CDCl}_{3}\right) \delta 5.64$ (app qt, $\left.J=6.3,0.7 \mathrm{~Hz}, 1 \mathrm{H}\right), 3.90-3.85(\mathrm{~m}, 1 \mathrm{H}), 3.39-3.28$ (m, 3H), 3.04 (app d, $J=14.8 \mathrm{~Hz}, 1 \mathrm{H}), 2.41(\mathrm{dd}, J=14.8,9.1 \mathrm{~Hz}, 1 \mathrm{H}), 2.02(\mathrm{~m}, 1 \mathrm{H}), 1.75(\mathrm{~d}$, $J=6.3 \mathrm{~Hz}, 3 \mathrm{H}), 1.68-1.62(\mathrm{~m}, 2 \mathrm{H}), 1.54-1.44(\mathrm{~m}, 1 \mathrm{H}), 0.96(\mathrm{t}, J=7.9 \mathrm{~Hz}, 9 \mathrm{H}), 0.59(\mathrm{q}, J=$ $7.8 \mathrm{~Hz}, 6 \mathrm{H}) ;{ }^{13} \mathbf{C}$ NMR $\left(125 \mathrm{MHz}, \mathrm{CDCl}_{3}\right) \delta 131.5,107.3,81.3,70.8,68.1,47.8,33.8,25.8$, 22.5, 7.1, 5.3.

HR-MS (ESI) $\mathrm{m} / z$ calcd for $\mathrm{C}_{15} \mathrm{H}_{29} \mathrm{IO}_{2} \mathrm{Si}(\mathrm{M}+\mathrm{Na})^{+}$: 419.0874, found 419.0893.

\subsection{Preparation of trisubstituted alkene 20 by carbometalation}

To a of bishomopropargylic alcohol 19 in $\mathrm{CH}_{2} \mathrm{Cl}_{2}(10 \mathrm{~mL})$ at $0^{\circ}$ was added slowly a $2 \mathrm{M}$ solution of $\mathrm{AlMe}_{3}$ in hexanes $(0.96 \mathrm{~mL}, 1.93 \mathrm{mmol}) .{ }^{\mathrm{S} 10}$ This solution was stirred for $3 \mathrm{~min}$. and then recooled to $-78^{\circ}$. A $1 \mathrm{M}$ solution of $\mathrm{TiCl}_{4}$, in $\mathrm{CH}_{2} \mathrm{Cl}_{2}(0.96 \mathrm{~mL}, 0.96 \mathrm{mmol})$ was added dropwise. The solution was stirred $2 \mathrm{~h}$. at $-78^{\circ}$ and then quenched with cold $\mathrm{MeOH}$ (1 $\mathrm{mL})$, upon which the solution turned pale yellow. The solution was diluted with $\mathrm{Et}_{2} \mathrm{O}(10 \mathrm{~mL})$ and washed with a saturated solution of Rochelle's salt $(10 \mathrm{~mL})$. The aqueous layer was extracted with $\mathrm{Et}_{2} \mathrm{O}(3 \times 20 \mathrm{ml})$, dried over $\mathrm{MgSO}_{4}$, and concentrated in vacuo, and this crude product was purified by column chromatography (25\% EtOAc in hexanes) to afford $\mathbf{2 0}$ as a colorless oil (105 mg, $0.62 \mathrm{mmol}, 70 \%)$ : $\mathbf{R}_{\mathbf{f}}=0.38$ (30\% EtOAc in hexanes); $[\boldsymbol{\alpha}]^{\mathbf{2 2}} \mathbf{D}=-19.4$ $\left(c=1.2, \mathrm{CDCl}_{3}\right)$. Some unreacted $19(16 \mathrm{mg}, 0.10 \mathrm{mmol}, 12 \%)$ was also recovered.

IR (thin film, NaCl) 3412, 2928, 2855, 1451, 1376, 1340, 1277, 1095, 1036, $944 \mathrm{~cm}^{-1}$

${ }^{1} \mathbf{H}$ NMR $\left(500 \mathrm{MHz}, \mathrm{CDCl}_{3}\right) \delta 5.29(\mathrm{app} \mathrm{t}, J=7.0 \mathrm{~Hz}, 1 \mathrm{H}), 3.94-3.89(\mathrm{~m}, 1 \mathrm{H}), 3.42-3.30(\mathrm{~m}$, 2H), 3.08 (ddd, $J=8.7,7.2,4.5 \mathrm{~Hz}, 1 \mathrm{H}), 2.52$ (app dt, $J=15.0,5.8 \mathrm{~Hz}, 1 \mathrm{H}), 2.24$ (app dt, $J=$ 15.0, $7.0 \mathrm{~Hz}, 1 \mathrm{H}), 2.10(\mathrm{~m}, 1 \mathrm{H}), 1.73(\mathrm{~s}, 3 \mathrm{H}), 1.72-1.64(\mathrm{~m}, 5 \mathrm{H}), 1.40$ (dddd, $J=17.4,11.3$, 6.3, $5.4 \mathrm{~Hz}, 1 \mathrm{H}) ;{ }^{13} \mathbf{C}$ NMR $\left(100 \mathrm{MHz}, \mathrm{CDCl}_{3}\right) \delta 134.1,120.5,82.4,70.9,67.9,32.8,31.6$, 26.1, 25.7, 18.2.

HR-MS (ESI) $m / z$ calcd for $\mathrm{C}_{10} \mathrm{H}_{18} \mathrm{O}_{2}(\mathrm{M}+\mathrm{Na})^{+}:$193.1199, found 193.1194 .

\subsection{Preparation of alkenyl bromide 28 by bromoallylation}

To $\mathrm{PdCl}_{2}(\mathrm{PhCN})_{2}(40 \mathrm{mg}, 0.11 \mathrm{mmol})$ and $\mathrm{NaHCO}_{3}(880 \mathrm{mg}, 10.5 \mathrm{mmol})$ was added allyl bromide ( $9 \mathrm{~mL}, 105 \mathrm{mmol})$. The resulting solution was stirred 15 minutes at room temperature. Alkyne 26 (795 mg, $2.1 \mathrm{mmol})$ as a solution in THF ( $2 \mathrm{~mL})$ was then added dropwise at ambient temperature via syringe pump over $90 \mathrm{~min}$. After addition the reaction was stirred a further 30 min., directly concentrated in vacuo, and chromatographed (gradient $2 \%$ to 3\% to 5\% EtOAc in hexanes) to afford alkenyl bromide $\mathbf{2 8}(920 \mathrm{mg}, 1.84 \mathrm{mmol}, 88 \%)$ : $\mathbf{R}_{\mathbf{f}}=0.54$ (10\% EtOAc in hexanes); $[\boldsymbol{\alpha}]^{22} \mathbf{D}=-11.5\left(c=27.0, \mathrm{CDCl}_{3}\right)$. 
IR (thin film, NaCl) 3072, 3011, 2933, 2858, 1639, 1472, 1428, 1362, 1218, 1127, 1103, 1048 $\mathrm{cm}^{-1}$.

${ }^{1} \mathbf{H}$ NMR $\left(500 \mathrm{MHz}, \mathrm{CDCl}_{3}\right) \delta 7.87$ (app t, $\left.J=8.4 \mathrm{~Hz}, 4 \mathrm{H}\right), 7.56-7.46(\mathrm{~m}, 6 \mathrm{H}), 5.92$ (dddd, $J=16.5,10.1,6.2,6.2 \mathrm{~Hz}, 1 \mathrm{H}), 5.85($ app t, $J=6.8 \mathrm{~Hz}, 1 \mathrm{H}), 5.22(\mathrm{dd}, J=17.1,1.7 \mathrm{~Hz}, 1 \mathrm{H})$, $5.13(\mathrm{dd}, J=10.1,1.5 \mathrm{~Hz}, 1 \mathrm{H}), 3.92-3.87(\mathrm{~m}, 1 \mathrm{H}), 3.71(\mathrm{app} \mathrm{td}, J=9.2,1.5 \mathrm{~Hz}, 1 \mathrm{H}), 3.55$ (ddd, $J=10.2,9.1,4.6 \mathrm{~Hz}, 1 \mathrm{H}), 3.39(\operatorname{app} t \mathrm{td}, J=11.3,2.7 \mathrm{~Hz}, 1 \mathrm{H}), 3.32(\operatorname{app} \mathrm{d}, J=14.7 \mathrm{~Hz}$, $1 \mathrm{H}), 3.13-3.02(\mathrm{~m}, 2 \mathrm{H}), 2.43(\mathrm{dd}, J=14.8,10.0 \mathrm{~Hz}, 1 \mathrm{H}), 2.05-2.00(\mathrm{~m}, 1 \mathrm{H}), 1.70-1.62(\mathrm{~m}$, 1H), 1.60-1.48 (m, 2H), 1.23 (s, 9H); ${ }^{13} \mathbf{C}$ NMR (125 MHz, $\left.\mathrm{CDCl}_{3}\right) \delta$ 135.9, 135.9, 134.9, 134.3, 133.5, 129.9, 129.7, 127.8, 127.6, 126.0, 115.5, 80.0, 71.9, 67.6, 44.5, 35.8, 33.5, 27.1, 25.5, 19.3.

HR-MS (ESI) $\mathrm{m} / z$ calcd for $\mathrm{C}_{27} \mathrm{H}_{35} \mathrm{BrO}_{2} \mathrm{Si}(\mathrm{M}+\mathrm{Na})^{+}$: 521.1482, found 521.1489.

\subsection{Preparation of alkenyl boronate ester 35 by hydroboration}

Alkyne 32 (616 mg, $1.56 \mathrm{mmol}$ ) was added to a dry, cooled sealed tube. The tube was pumped under high vacuum and then backfilled with argon three times. Pinacolborane $(287 \mu \mathrm{L}, 253$ $\mathrm{mg}, 1.98 \mathrm{mmol})$ was added, followed by $\mathrm{Et}_{3} \mathrm{~N}(22 \mu \mathrm{L}, 16 \mathrm{mg}, 0.16 \mathrm{mmol})$ and Schwartz's reagent $(41 \mathrm{mg}, 0.16 \mathrm{mmol})$. The resulting slurry was heated to $60^{\circ}$ and stirred vigorously for $28 \mathrm{~h}$. while protected from light. After cooling, the crude reaction mixture was filtered through a short pad of $\mathrm{SiO}_{2}\left(100 \% \mathrm{Et}_{2} \mathrm{O}\right)$ and concentrated in vacuo to a heavy oil containing a 2:1 mixture of pinacolate $35\left(\mathbf{R}_{\mathbf{f}}=0.36,10 \%\right.$ EtOAc in hexanes $)$ and its regioisomer $\mathbf{3 6}\left(\mathbf{R}_{\mathbf{f}}=0.38\right.$, $10 \%$ EtOAc in hexanes), along with unreacted $\mathbf{3 2}$, traces of a proton quench product, and borate and other impurities. These were separated via careful column chromatography (gradient $3 \%$ to 5\% EtOAc in hexanes) to afford 35 (235 $\mathrm{mg}, 0.45 \mathrm{mmol}, 29 \%$ (39\% based on recovered 32) in $>20: 1$ regioisomeric purity along with unreacted $32(163 \mathrm{mg}, 26 \%):[\alpha]^{22} \mathrm{D}=-2.1(c=$ $\left.1.9, \mathrm{CDCl}_{3}\right)$.

IR (thin film, NaCl) 3072, 2932, 2246, 1632, 1472, 1428, 1371, 1301, $1103 \mathrm{~cm}^{-1}$

${ }^{1}$ H NMR $\left(500 \mathrm{MHz}, \mathrm{CDCl}_{3}\right) \delta$ 7.71-7.67 (m, 4H), 7.45-7.36 (m, 6H), 6.43 (app tq, $J=6.4$, $1.5 \mathrm{~Hz}, 1 \mathrm{H}), 3.81-3.76(\mathrm{~m}, 1 \mathrm{H}), 3.45-3.39(\mathrm{~m}, 1 \mathrm{H}), 3.30-3.24(\mathrm{~m}, 2 \mathrm{H}), 2.81-2.75(\mathrm{~m}, 1 \mathrm{H})$, 2.08-2.00 (m, 1H), 1.82-1.77 (m, 1H), $1.63(\mathrm{~d}, J=1.5 \mathrm{~Hz}, 3 \mathrm{H}), 1.49-1.38(\mathrm{~m}, 3 \mathrm{H}), 1.27$ (app s, $12 \mathrm{H}), 1.04(\mathrm{~s}, 9 \mathrm{H}) ;{ }^{\mathbf{1 3}} \mathbf{C}$ NMR $\left(125 \mathrm{MHz}, \mathrm{CDCl}_{3}\right) \delta 143.43,136.1,136.1,134.9,133.9$, $129.9,129.7,127.9,127.6,83.3,82.4,72.6,67.9,33.6,32.1,27.2,25.8,25.1,25.0,19.5,14.5$ (no signal was observed for the boron-bound carbon).

HR-MS (ESI) $m / z$ calcd for $\mathrm{C}_{31} \mathrm{H}_{46} \mathrm{BO}_{4} \mathrm{Si}(\mathrm{M}+\mathrm{Na})^{+}:$543.3089, found 543.3089.

\subsection{Preparation of diepoxide 42 by Pd-catalyzed cross-coupling and Shi $\mathrm{AE}$}

[1, 1'-Bis(diphenylphosphino)ferrocene] dichloropalladium(II) $\left(\mathrm{PdCl}_{2}\right.$ (dppf)) $(73 \mathrm{mg}, 0.10$ mmol) was added to a flame-dried, cooled sealed tube. $\mathrm{K}_{3} \mathrm{PO}_{4}(1.83 \mathrm{~g}, 8.63 \mathrm{mmol})$ was added, and the tube was pumped under high vacuum and backfilled with argon three times. Alkenyl boronate $35(600 \mathrm{mg}, 1.15 \mathrm{mmol})$ was then added as a solution in dry THF $(2 \mathrm{~mL})$. The mixture was allowed to stir under Ar for $5 \mathrm{~min}$. Degassed water $(42 \mathrm{mg}, 42 \mu \mathrm{L}, 2.3 \mathrm{mmol}$, degassed via sparging) was then added, followed immediately by prenyl bromide $(859 \mathrm{mg}, 666 \mu \mathrm{L}, 5.76$ $\mathrm{mmol}$ ). The sealed tub was capped, and the slurry was heated to $80^{\circ}$ and stirred vigorously for $42 \mathrm{~h}$. After cooling and dilution with $\mathrm{Et}_{2} \mathrm{O}(5 \mathrm{~mL})$, the crude product was filtered through $\mathrm{SiO}_{2}$ (washed with $\mathrm{Et}_{2} \mathrm{O}$ ) and concentrated in vacuo to yield a 2.5:1 mixture of $\mathbf{3 9}$ and $\mathbf{4 0}$. These inseparable diene isomers were purified away from phosphine and other impurities via column chromatography (gradient $2 \%$ to $3 \%$ EtOAc in hexanes) to give a 2.5:1 mixture of 39:40 (400 mg, $0.86 \mathrm{mmol}, 75 \%$ combined yield, $\mathbf{R}_{\mathbf{f}}=0.63,10 \%$ EtOAc in hexanes). This mixture was carried forward into Shi epoxidation without further purification. 
To this mixture ( $400 \mathrm{mg}, 0.86 \mathrm{mmol})$ in 2:1 v/v DMM:MeCN $(23.2 \mathrm{~mL}$ ) was added a $0.05 \mathrm{M}$ solution of $\mathrm{Na}_{2} \mathrm{~B}_{4} \mathrm{O}_{7} \bullet 10 \mathrm{H}_{2} \mathrm{O}$ in $4 \times 10^{-4} \mathrm{Na}_{2} \mathrm{EDTA}(15.5 \mathrm{~mL}), n \mathrm{Bu}_{4} \mathrm{HSO}_{4}(75 \mathrm{mg}, 0.22 \mathrm{mmol})$, and chiral ketone $18(222 \mathrm{mg}, 0.86 \mathrm{mmol})$. This biphasic mixture was stirred vigorously at $0^{\circ}$. To this mixture was added, simultaneously over $30 \mathrm{~min}$. via syringe pump, a solution of Oxone $(1.06 \mathrm{~g}, 1.73 \mathrm{mmol})$ in $4 \times 10^{-4} \mathrm{Na}_{2} \mathrm{EDTA}(7.75 \mathrm{~mL})$ and a $0.89 \mathrm{M}$ solution of $\mathrm{K}_{2} \mathrm{CO}_{3}(7.75$ $\mathrm{mL}, 6.9 \mathrm{mmol})$. After the $\mathrm{K}_{2} \mathrm{CO}_{3}$ and Oxone solutions had been added, the resulting mixture was stirred an additional $20 \mathrm{~min}$., at which point it was diluted with EtOAc $(25 \mathrm{~mL})$. The aqueous layer was extracted with EtOAc $(3 \times 25 \mathrm{~mL})$, and the combined organics were washed with sat. $\mathrm{NaCl}$, dried over $\mathrm{MgSO}_{4}$, and concentrated in vacuo to provide desired diepoxide $\mathbf{4 2}$ and diastereomers. $\mathbf{4 0}$ was partially oxidized under these conditions to monoepoxide $\mathbf{4 1}$ $\left(\mathrm{R}_{\mathrm{f}}=0.77,20 \%\right.$ EtOAc in hexanes. Column chromatography (15\% EtOAc in hexanes) afforded diepoxide $\mathbf{4 2}$ in 3.5:1 overall $\mathrm{dr}$ as a colorless oil (276 mg, $0.56 \mathrm{mmol}, 65 \%$ (49\% yield over 2 steps), $\mathbf{R}_{\mathbf{f}}=0.54$ (20\% EtOAc in hexanes)) contaminated with a small quantity of ketone 18. Diepoxide 42 was further purified via preparative HPLC (Supelco SUPELCOSIL LC-SI $20 \mathrm{~mm}$ achiral $\mathrm{SiO}_{2}$ column, $5 \mu \mathrm{m}$ particle size; 99.5:0.5 hexanes: $\mathrm{iPrOH}, 20 \mathrm{~mL} / \mathrm{min}$.; $\mathrm{t}_{\mathrm{R}}$ of desired diastereomer $=11.9 \mathrm{~min}$.) to afford $\mathbf{4 2}$ free of $\mathbf{2 0}$ and in 15:1 to 20:1 overall $\mathrm{dr}$ (depending on batch): $[\alpha]^{22}$ D for a sample in $20: 1 \mathrm{dr}=-7.5\left(c=3.3, \mathrm{CDCl}_{3}\right)$.

IR (thin film, NaCl) 3072, 2958, 2930, 2857, 1590, 1472, 1462, 1428, 1379, $1102 \mathrm{~cm}^{-1}$

${ }^{1} \mathbf{H}$ NMR $\left(500 \mathrm{MHz}, \mathrm{CDCl}_{3}\right) \delta$ 7.71-7.66 (m, 4H), 7.46-7.41 (m, 2H), 7.40-7.36 (m, 4H), 3.85-3.80 (m, 1H), 3.43 (ddd, $J=9.3,4.8,4.5 \mathrm{~Hz}, 1 \mathrm{H}), 3.29$ (app td, $J=9.3,2.5 \mathrm{~Hz}, 1 \mathrm{H}$ ), 2.93 (app t, $J=6.1 \mathrm{~Hz}, 1 \mathrm{H}), 2.89$ (app t, $J=6.0 \mathrm{~Hz}, 1 \mathrm{H}), 2.11(\mathrm{ddd}, J=14.4,6.4,2.7 \mathrm{~Hz}, 1 \mathrm{H})$, $1.85-1.80(\mathrm{~m}, 1 \mathrm{H}), 1.77-1.73(\mathrm{~m}, 2 \mathrm{H}), 1.60(\mathrm{ddd}, J=14.9,9.5,5.8 \mathrm{~Hz}, 1 \mathrm{H}), 1.51-1.39(\mathrm{~m}, 3 \mathrm{H})$, 1.33 (app s, 6H), 1.27 (s, 3H), 1.04 (s, 9H); $\left.{ }^{13} \mathbf{C ~ N M R ~ ( 1 0 0 ~ M H z , ~} \mathrm{CDCl}_{3}\right) \delta 136.1,136.1$, 134.7, 133.6, 130.0, 129.8, 127.9, 127.7, 81.4, 72.5, 67.9, 61.3, 61.2, 58.8, 58.0, 38.2, 33.5, $31.8,27.2,25.6,24.9,19.5,19.0,17.3$.

HR-MS (ESI) $m / z$ calcd for $\mathrm{C}_{30} \mathrm{H}_{42} \mathrm{O}_{4} \mathrm{Si}(\mathrm{M}+\mathrm{Na})^{+}:$517.2745, found 517.2751.

\section{Acknowledgments}

This work was supported by the NIGMS (GM72566). C.J.M. thanks the George Büchi Summer Graduate Fellowship for fellowship support. Li Li (MIT) acquired HR-MS data. We are grateful also to Dr. Jeffery A. Byers, Aaron van Dyke, Ivan Vilotijevic, and Brian S. Underwood (all of MIT) for many helpful discussions. Without their insights this work would not have been possible.

\section{References}

i. Wilson SR, Zucker PA. J. Org. Chem 1988;53:4682.

ii. Nicolaou KC, Frederick MO, Aversa RJ. Angew. Chem. Int. Ed 2008;47:7182.

iii. (a) Nakanishi K. Toxicon 1985;23:473. [PubMed: 3895583] (b) Lee MS, Qin G-W, Nakanishi K, Zagorski MG. J. Am. Chem. Soc 1989;111:6234.(c) Shimizu, Y. Natural Toxins: Animal, Plant, and Microbial. Harris, JB., editor. Oxford: Clarendon; 1986. p. 123

iv. Gallimore AR, Spencer JB. Angew. Chem. Int. Ed 2006;45:4406.

v. (a) Wang Z-X, Tu Y, Frohn M, Zhang J-R, Shi Y. J. Am. Chem. Soc 1997;119:11224. (b) Frohn M, Dalkiewicz M, Tu Y, Wang Z-X, Shi Y. J. Org. Chem 1998;63:2948. (c) Shi Y. Acc. Chem. Res 2004;37:488. [PubMed: 15311947]

vi. (a) Carruthers, W.; Coldham, I. Modern Methods of Organic Synthesis. Cambridge: Cambridge, UK; 2006. p. 105-158.(b) Williams, JM., editor. Preparation of Alkenes, A Practical Approach. New York: Oxford; 1996. (c) Flynn AB, Ogilvie WW. Chem. Rev 2007;107:4698. [PubMed: 17973435] vii. Bordwell FG, Drucker GE, Fried HE. J. Org. Chem 1981;46:632.

viii. The bond dissociation energy of the doubly allylic $\mathrm{C}-\mathrm{H}$ bonds in 1,4-pentadiene is quite low; it has been measured at $68.5 \mathrm{kcal} / \mathrm{mol}$. See: McMahon TB, Kebarle P. J. Am. Chem. Soc 1974;96:5940. 
ix. Hixson SS, Mariano PS, Zimmerman HE. Chem. Rev 1973;73:531.

x. (a) Heffron TP, Jamison TF. Org. Lett 2003;5:2339. [PubMed: 12816443] (b) Heffron TP, Trenkle JD, Jamison TF. Tetrahedron 2003;59:8913. (c) Simpson GL, Heffron TP, Merino E, Jamison TF. J. Am. Chem. Soc 2006;128:1056. [PubMed: 16433504]

xi. Vilotijevic I, Jamison TF. Science 2007;317:1189. [PubMed: 17761875]

xii. In Scheme 2, distal Me groups are shown in red and proximal in blue, for clarity.

xiii. For examples of highly endo-regioselective intramolecular opening of distally Me-substituted epoxides under acidic conditions, see: (a) Bravo F, McDonald FE, Neiwert WA, Do B, Hardcastle KI. Org Lett 2003;5:2123. [PubMed: 12790544] (b) Bravo F, McDonald FE, Neiwert WA, Hardcastle KI. Org Lett 2004;6:4487. [PubMed: 15548057] (c) Valentine JC, McDonald FE, Neiwert WA, Hardcastle KI. J. Am. Chem. Soc 2005;127:4586. [PubMed: 15796519] (d) Wan S, Gunaydin H, Houk KN, Floreancig PE. J. Am. Chem. Soc 2007;129:7915. [PubMed: 17547399] (e) Morimoto Y, Nishikawa Y, Ueba C, Tanaka T. Angew. Chem. Int. Ed 2006;45:810. For a canonical example of highly exo-regioselective intramolecular opening of proximally Mesubstituted epoxides under acidic conditions, see: (f) Xiong Z, Corey EJ. J. Am. Chem. Soc 2000;122:9328.

xiv. Morten CJ, Jamison TF. J. Am. Chem. Soc 2009;131:6678. [PubMed: 19402635]

xv. (a) Schiavelli MD, Plunkett JJ, Thompson DW. J. Org. Chem 1981;46:807. (b) Ewing JC, Ferguson GS, Moore DW, Shultz FW, Thompson DW. J. Org. Chem 1985;50:2124.

xvi. (a) Kaneda K, Kawamoto F, Fujiwara Y, Imanaka T, Teranishi S. Tetrahedron Lett 1974;12:1067. (b) Kaneda K, Uchiyama T, Fujiwara Y, Imanaka T, Teranishi S. J. Org. Chem 1979;44:55.

xvii. A racemic synthesis of $\mathbf{4}$ was reported by Bowman and McDonald: (a) Bowman JL, McDonald FE. J. Org. Chem 1998;63:3680-3682. (+)-4, the enantiomer of 4, has been prepared by the Nakata group: (b) Matsuo G, Hinou H, Koshino H, Suenaga T, Nakata T. Tetrahedron Lett 2000;41:903906. (c) Suzuki K, Nakata T. Org. Lett 2002;4:2739-2741. [PubMed: 12153223] A previous asymmetric syntheses of $\mathbf{4}$ by the Jamison group are reported in reference 10a. We report a streamlined gram-scale synthesis of 4, requiring five steps from 2,3-dihydropyran, in the Supporting Information to reference 14.

xviii. Initial report: (a) Van Horn DE, Negishi E. J. Am. Chem. Soc 1978;100:2252. Successful carbometallation in the presence of free hydroxyl groups: (b) Rand CL, Van Horn DE, Moore MW, Negishi E-I. J. Org. Chem 1981;46:4093. Recent review (c) Negishi E-I. Dalton Trans 2005:827. [PubMed: 15726133]

xix. Wipf P, Lim S. Angew. Chem. Int. Ed. Engl 1993;32:1068.

xx. Marfat A, McQuirk PR, Helquist P. Tetrahedron Lett 1978;19:1363.

xxi. For a general review of the 1,2-difunctionalization of alkynes via metallometalation, see: (a) Beletskaya I, Moberg C. Chem. Rev 1999;99:3435. [PubMed: 11849027] For a recent review of silylcupration, see: (b) Barbero A, Pulido FJ. Chem. Res 2004;37:817. For a recent review of stannylcupration, see: (c) Barbero A, Pulido FJ. Chem. Soc. Rev 2005;34:913. [PubMed: 16239993]

xxii. The conditions that effected a trace of the desired product were taken from: Barbero A, Cuadrado P, Flemin I, González AM, Pulido FJ, Rubio R. J. Chem. Soc. Perkin Trans 1993;1:1657.

xxiii. Nagamitsu T, Takano D, Fukuda T, Otoguro K, Kuwajima I, Harigaya Y, Omura S. Org. Lett 2004;6:1865. [PubMed: 15151434]

xxiv. For a few examples of the manifold potential electrophilic quenches and transmetalation possibilities open to alkenylaluminum and alkenylcopper species, including conjugated additions, transmetalation to Pd and subsequent cross-coupling, see: (a) Marfat A, McQuirk PR, Kramer R, Helquist PJ. J. Am. Chem. Soc 1977;99:253. (b) Okukado N, Negishi E-I. Tetrahedron Lett 1978;27:2357. (c) Matsushita H, Negishi E-I. J. Am. Chem. Soc 2005;103:2882. (d) Williams DR, Shamin K. Org. Lett 2005;7:4161. [PubMed: 16146377] (e) DeBergh JR, Spivey KM, Ready JM. J. Am. Chem. Soc 2008;130:7828. [PubMed: 18517202]

xxv. (a) Thadani AN, Rawal VH. Org. Lett 2002;4:4317. [PubMed: 12443087] (b) Thadani AN, Rawal VH. Org. Lett 2002;4:4321. [PubMed: 12443088]

xxvi. Hoye TR, Wang J. J. Am. Chem. Soc 2005;127:6950. [PubMed: 15884928]

xxvii. Bäckvall J-E, Nilsson YIM, Gatti RGP. Organometallics 1995;14:4242.

xxviii. Winstein S, Young WG. J. Am. Chem. Soc 1936;58:104. 
xxix. Dai C, Fu GC. J. Am. Chem. Soc 2001;123:2719. [PubMed: 11456957]

xxx. The addition of $\mathrm{NaHCO}_{3}$ was found to improve yield slightly. Remarkably, a trace of silyl ether cleavage was observed in the absence of this base, presumably due to a small quantity of $\mathrm{HBr}$ in solution.

xxxi. For discussions of improving the stereoselectivity and reactivity of cross metatheses see: (a) Blackwell HE, O’Leary DJ, Chatterjee AK, Washenfelder RA, Bussmann DA, Grubbs RH. J. Am. Chem. Soc 2000;122:58. (b) Chatterjee AK, Choi T-L, Sanders DP, Grubbs RH. J. Am. Chem. Soc 2003;125:11360. [PubMed: 16220959] For a recent review, see (c) Connon SJ, Blecher S. Angew. Chem. Int. Ed 2003;42:1900.

xxxii. Patel J, Mujcinovic S, Jackson WR, Robinson AJ, Serelis AK, Such C. Green Chem 2006;8:450. xxxiii. Garber SB, Kingsbury JS, Gray BL, Hoveyda AH. J. Am. Chem. Soc 2000;122:8168.

xxxiv. Van Dyke AR, Jamison TF. Angew. Chem. Int. Ed 2009;48 in press.

xxxv. Wang YD, Kimball G, Prashad AS, Wang Y. Tetrahedron Lett 2005;46:8777.

xxxvi. Pereira S, Srebnik M. Organometallics 1995;14:3127.

xxxvii. Ishiyama T, Yamamoto M, Miyaura N. Chem. Lett 1996;25:1117.

xxxviii. For an overview of the bulky, electron-rich biaryl phosphines developed by the Buchwald group, see: (a) Mauger CC, Mignani GA. Aldrichimica Acta 2006;39:17. (b) Schlummer B, Scholz U. Adv. Synth. Catal 2004;346:1599. (c) Fors BP, Watson DA, Biscoe MR, Buchwald SL. J. Am. Chem. Soc 2008;130:13552. and references therein. [PubMed: 18798626]

xxxix. Nieto N, Molas P, Benet-Buchholz J, Vidal-Ferran A. J. Org. Chem 2005;70:10143. [PubMed: 16292858] 


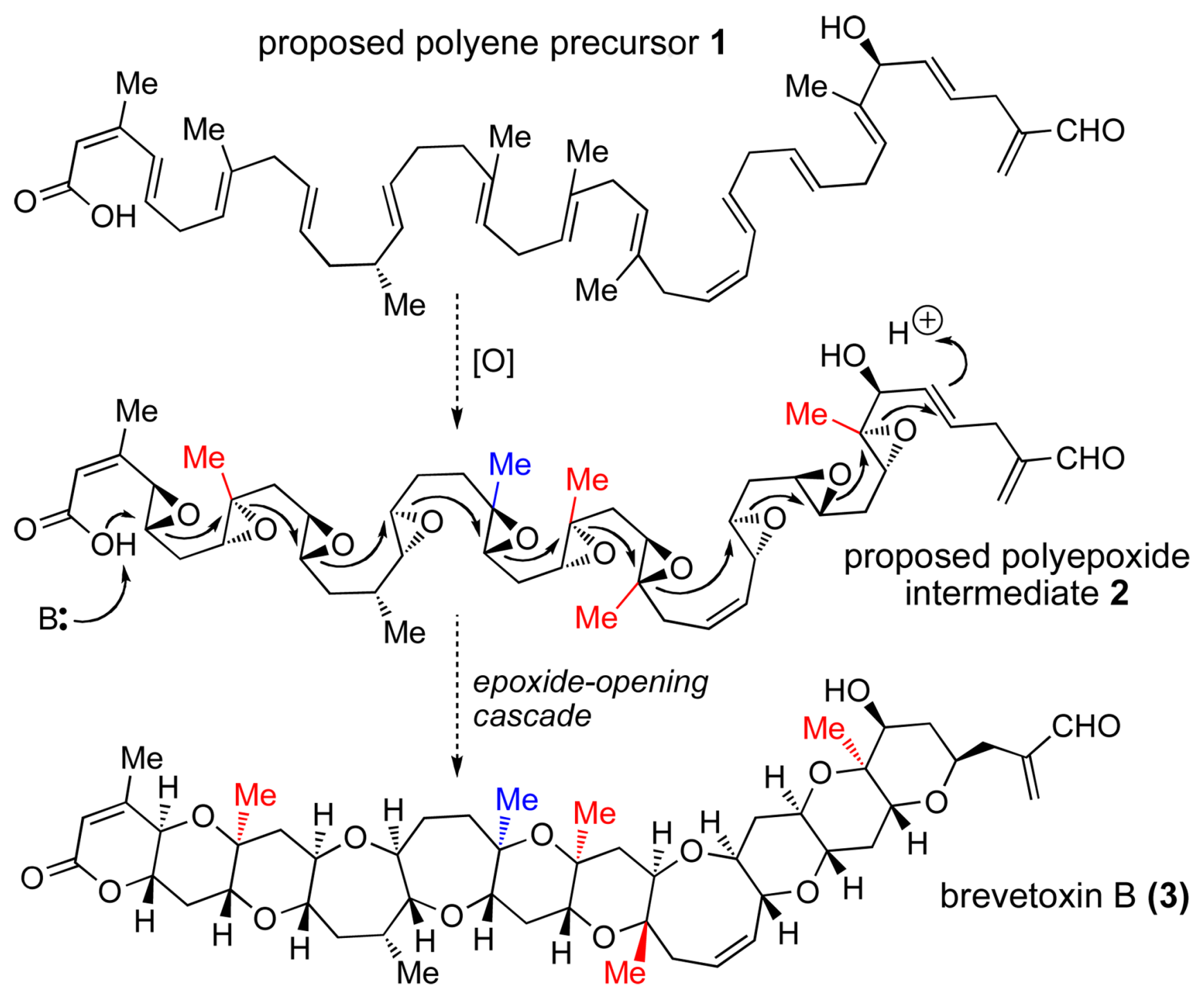

Scheme 1.

Nakanishi's proposed biosynthesis of brevetoxin B. 


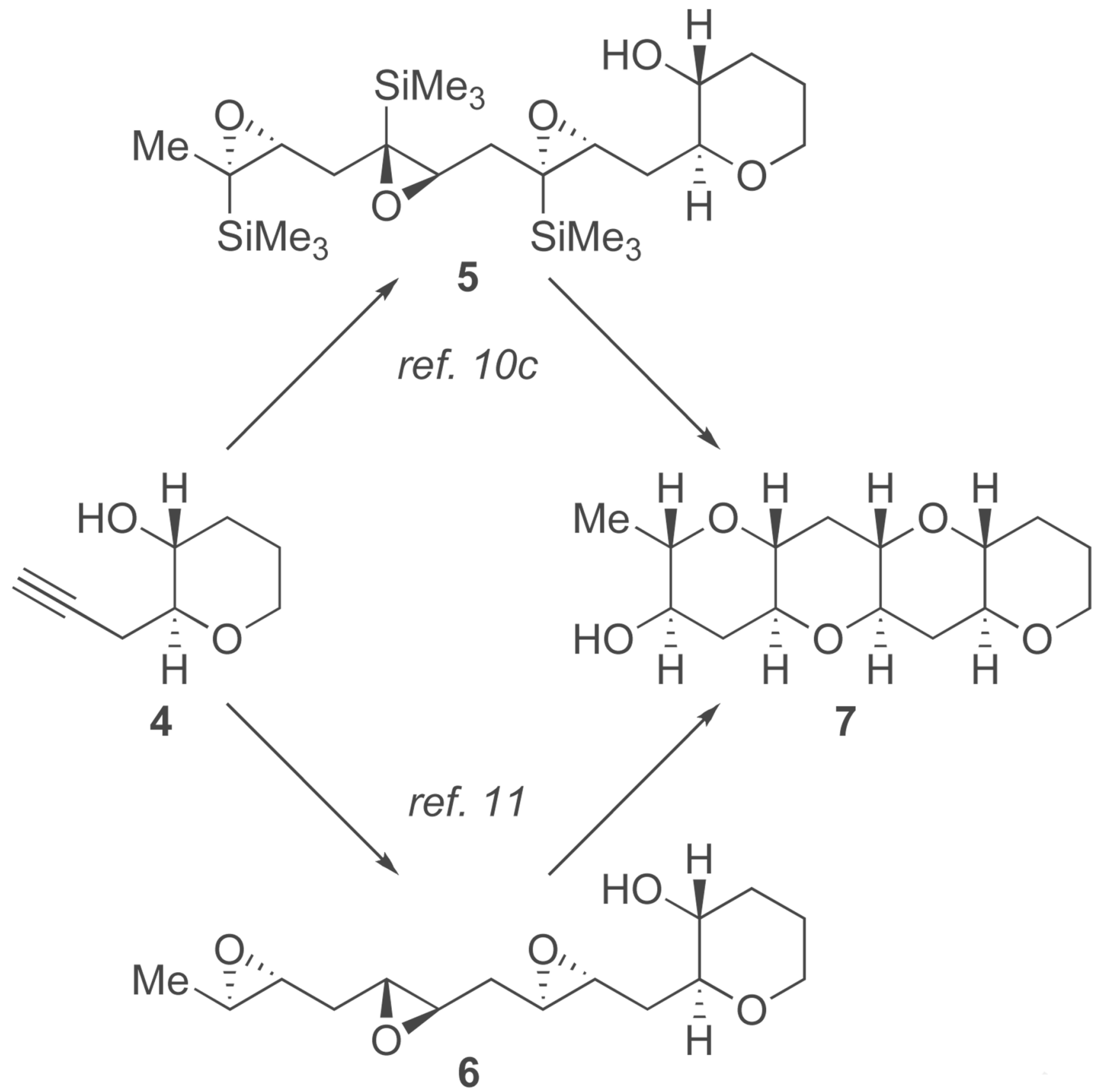

Scheme 2.

Previous polyepoxy alcohol syntheses from common intermediate 4 . 


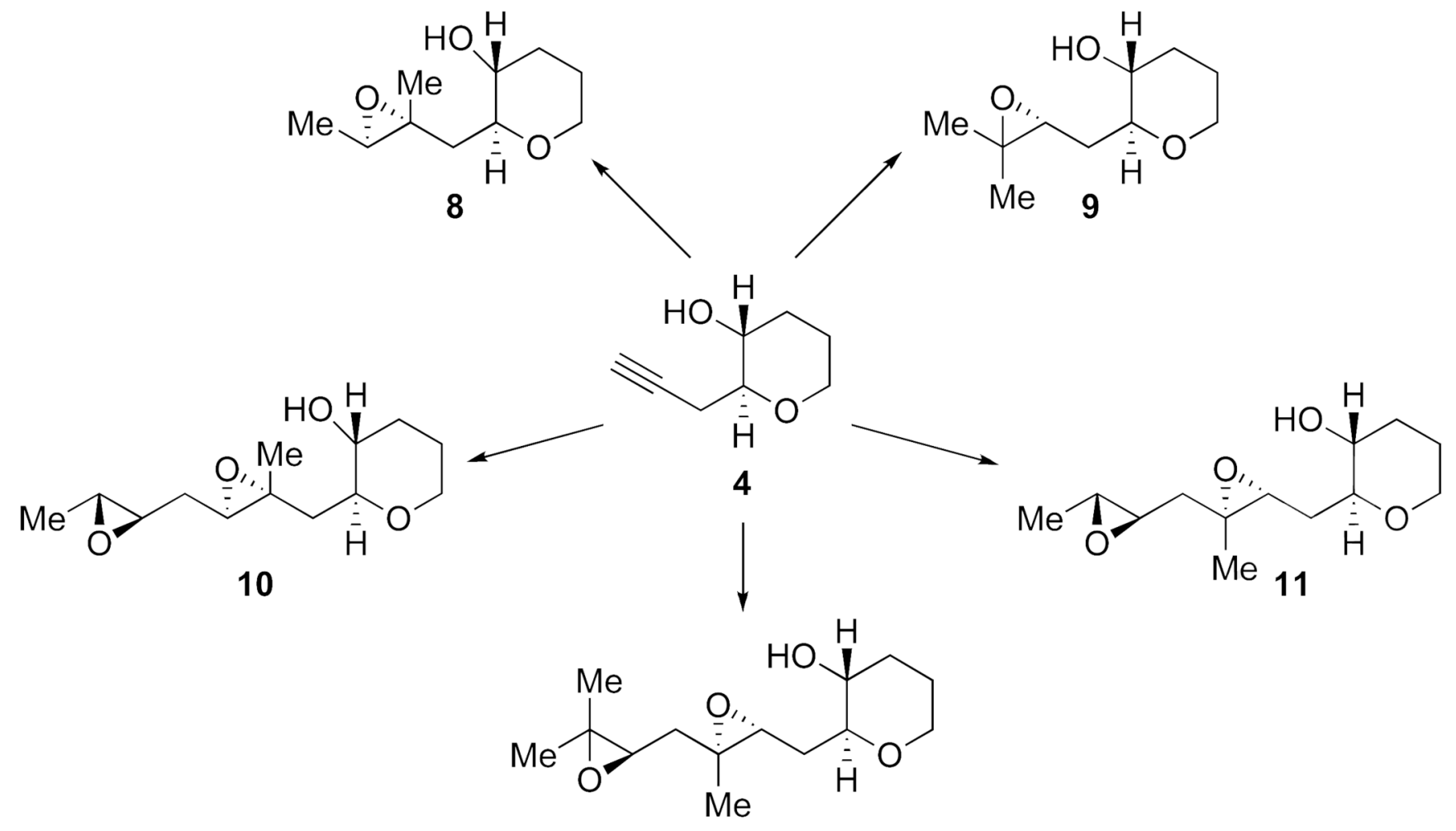

12

Scheme 3.

Mono- and diepoxy alcohols synthesized from bishomopropargylic alcohol 4. 
unsuccessful attempts at undirected carbometalation:

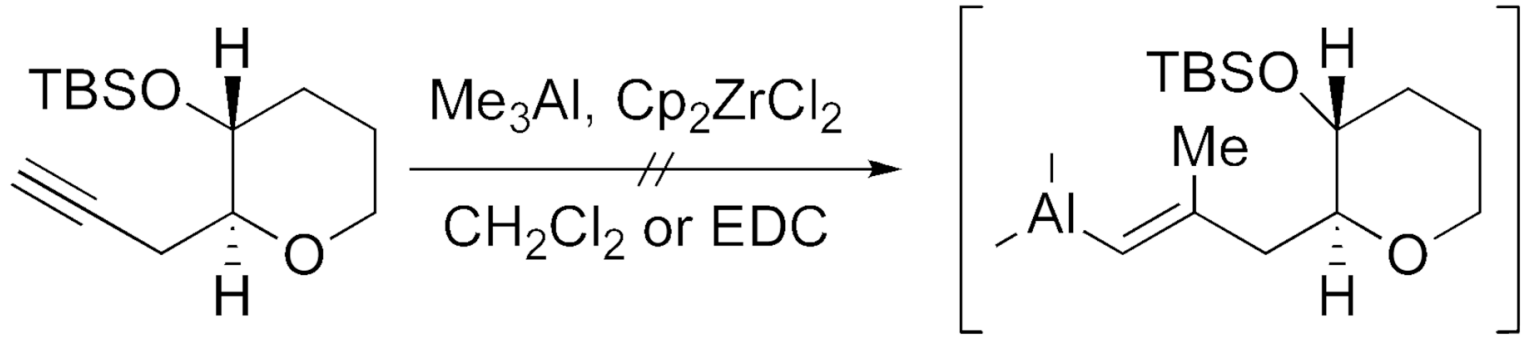

13

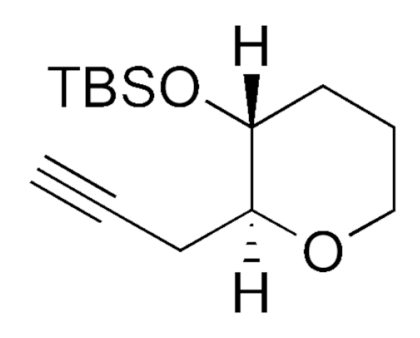

13

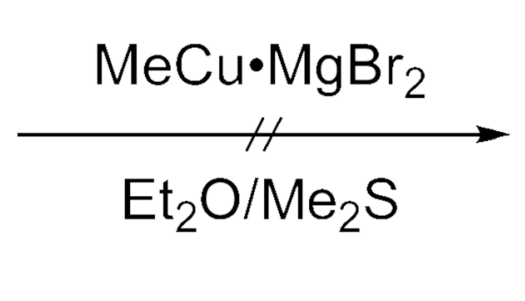

$\mathrm{Et}_{2} \mathrm{O} / \mathrm{Me}_{2} \mathrm{~S}$
14 not observed
15

not observed

successful directed carbometalation:

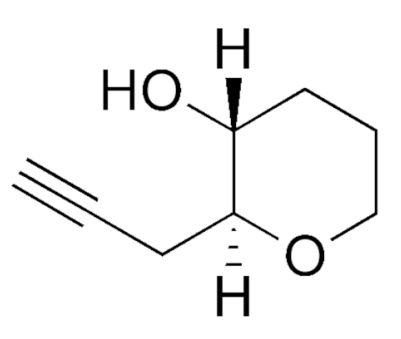

4 a) $\mathrm{AlMe}_{3}, \mathrm{TiCl}_{4}$;

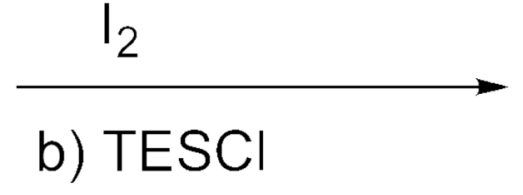

$\mathrm{Me}$

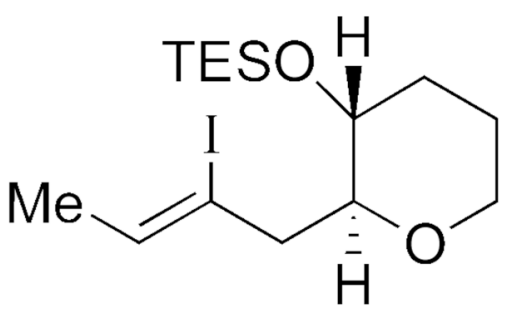

16

Scheme 4.

Carbometalation studies of 4 and 13. a) $\mathrm{AlMe}_{3}, \mathrm{TiCl}_{4}, \mathrm{CH}_{2} \mathrm{Cl}_{2},-78^{\circ}, 2$ h.; $\mathrm{I}_{2}, \mathrm{Et}_{2} \mathrm{O}$; b) TESCl, imid., DMF, $41 \%$ over 2 steps ( $45 \%$ brsm). 

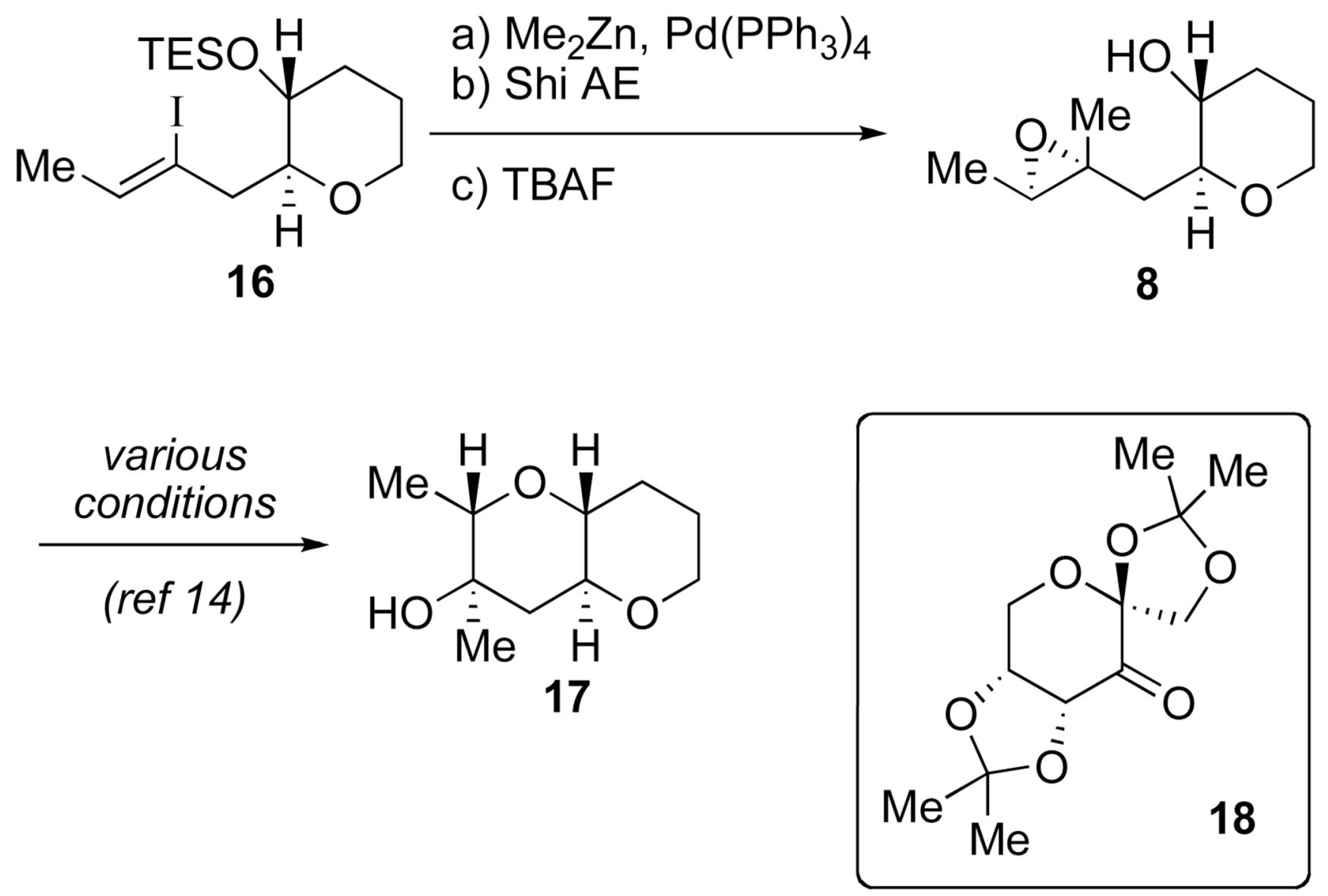

Scheme 5.

Synthesis of monoepoxy alcohol 8. a) $\mathrm{Me}_{2} \mathrm{Zn}, \mathrm{Pd}\left(\mathrm{PPh}_{3}\right)_{4}$, THF/PhMe, 85\%; b) chiral ketone 18, Oxone, $n \mathrm{Bu}_{4} \mathrm{NHSO}_{4}, \mathrm{~K}_{2} \mathrm{CO}_{3}, \mathrm{Na}_{2} \mathrm{~B}_{4} \mathrm{O}_{7}$ buffer, DMM/MeCN, $0^{\circ}, 71 \%, 2.8: 1 \mathrm{dr}$; c) TBAF, THF, $0^{\circ}, 94 \%$. 
<smiles>C#CC[C@H]1OCCC[C@H]1O</smiles>

d) TESCl

e) Shi AE

f) TBAF<smiles>CC1(C)OC1CC1OCCC[C@H]1O</smiles>

9

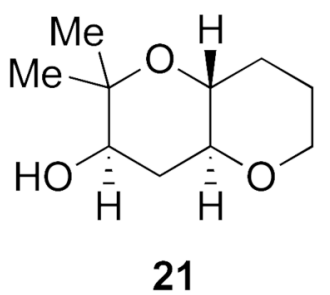

Scheme 6.

Synthesis of monoepoxy alcohol 9 a) TMSCl, HMDS, pyridine, $\mathrm{CH}_{2} \mathrm{Cl}_{2}, 90 \%$; b) $n \mathrm{BuLi}$, $\mathrm{Et}_{2} \mathrm{O} ; \mathrm{MeI} ; \mathrm{HCl}_{(\mathrm{aq})}, 88 \%$; c) $\mathrm{AlMe}_{3}, \mathrm{TiCl}_{4}, \mathrm{CH}_{2} \mathrm{Cl}_{2},-78^{\circ}, 2$ h.; $\mathrm{MeOH}, 70 \%$ (79\% brsm); d) TESCl, imid., DMF, 74\%; e) 18, Oxone, $n \mathrm{Bu}_{4} \mathrm{NHSO}_{4}, \mathrm{~K}_{2} \mathrm{CO}_{3}, \mathrm{Na}_{2} \mathrm{~B}_{4} \mathrm{O}_{7}$ buffer, DMM/ $\left.\mathrm{MeCN}, 0^{\circ}, 78 \%, 5.8: 1 \mathrm{dr} ; \mathrm{f}\right) \mathrm{TBAF}, \mathrm{THF}, 0^{\circ}, 98 \%$. 


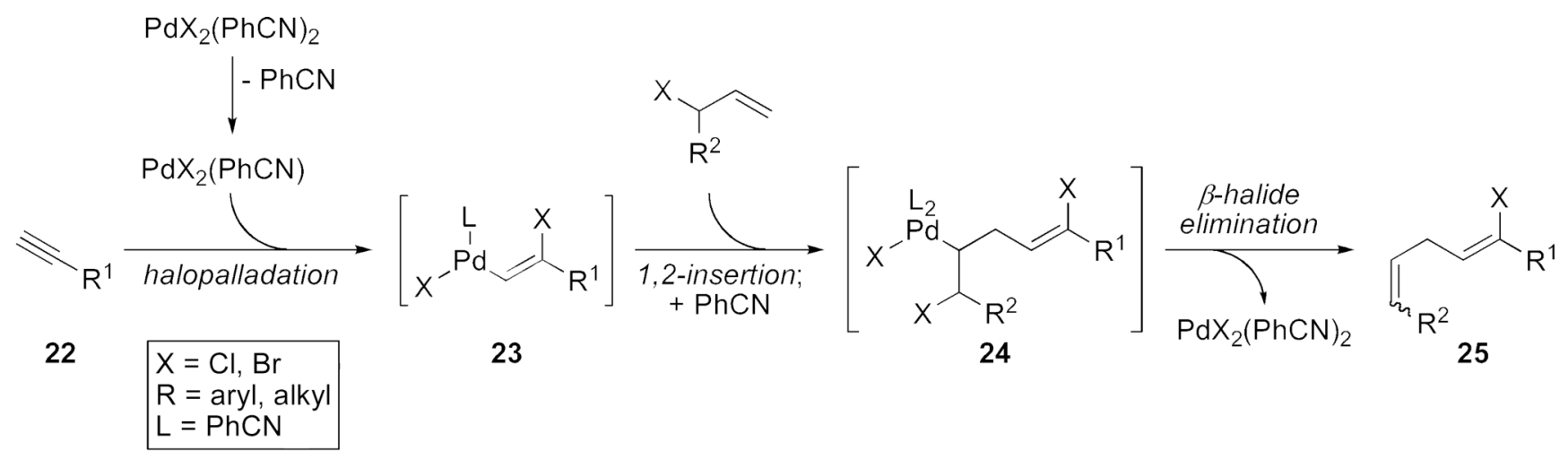

Scheme 7.

The mechanism for haloallylation proposed by Kaneda et al. 


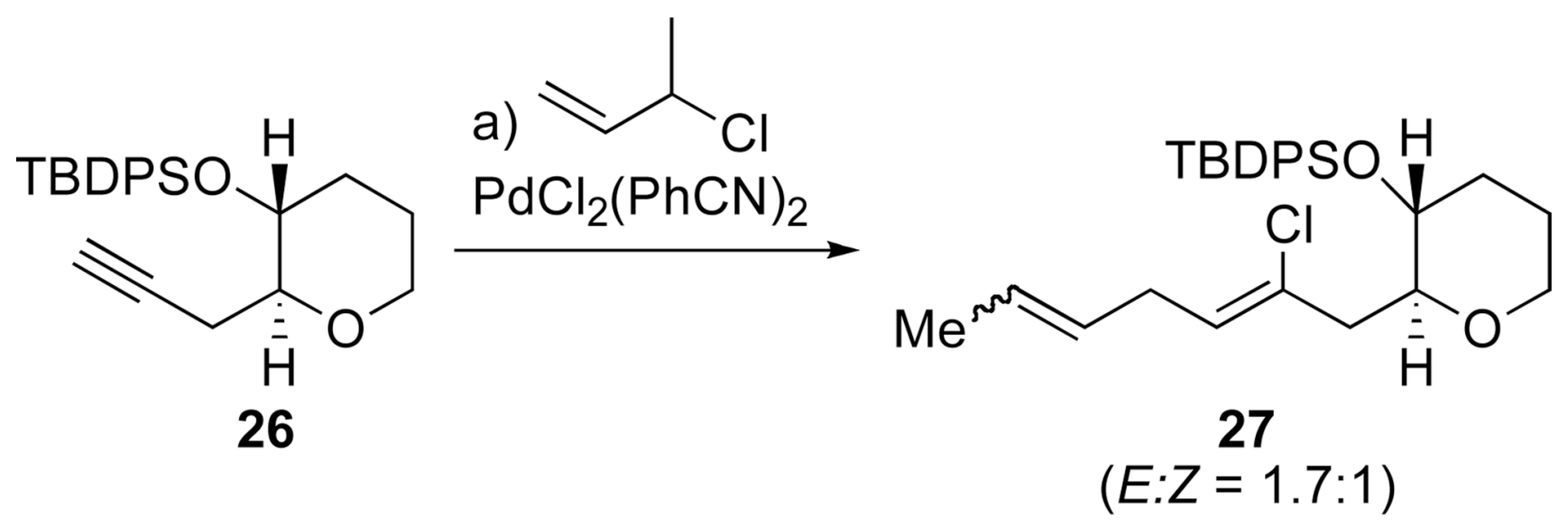

Scheme 8.

Chlorocrotylation of alkyne 26. a) 3-chloro-1-butene, $\mathrm{PdCl}_{2}(\mathrm{PhCN})_{2}, \mathrm{NaHCO}_{3}, \mathrm{THF}, 87 \%$, $1.7: 1 E: Z$ 


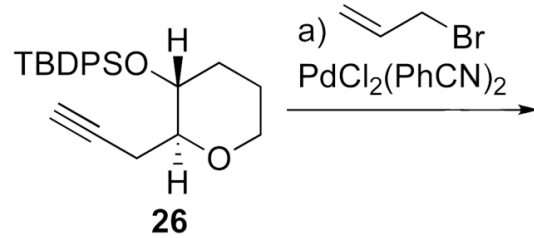

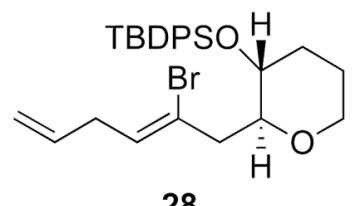

b) $\mathrm{Me}_{2} \mathrm{Zn}, \mathrm{Pd}\left(\mathrm{PPh}_{3}\right)_{4}$

c) Shi AE

28

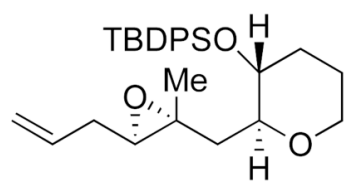

29

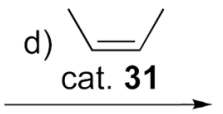

e) Shi AE

f) TBAF

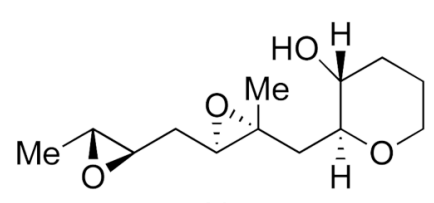

10

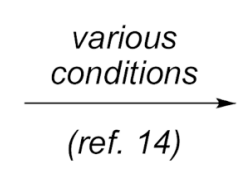

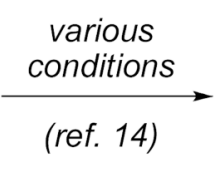

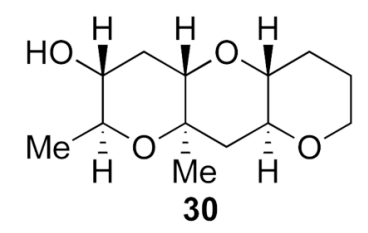

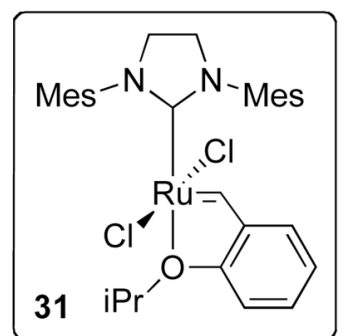

Scheme 9.

Synthesis of diepoxide 10. a) allyl bromide, $\mathrm{PdCl}_{2}(\mathrm{PhCN})_{2}, \mathrm{NaHCO}_{3}, \mathrm{rt}, 88 \%$; b) $\mathrm{Me}_{2} \mathrm{Zn}, \mathrm{Pd}$ $\left(\mathrm{PPh}_{3}\right)_{4}$, THF/PhMe; c) 18, Oxone, $n \mathrm{Bu}_{4} \mathrm{NHSO}_{4}, \mathrm{~K}_{2} \mathrm{CO}_{3}, \mathrm{Na}_{2} \mathrm{~B}_{4} \mathrm{O}_{7}$ buffer, DMM/MeCN, $0^{\circ}$, $48 \%$ over 2 steps, $4: 1 \mathrm{dr}$; d) cis-2-butene, Hoveyda-Grubbs $2^{\text {nd }}$ gen. catalyst $\mathbf{3 1}, \mathrm{CH}_{2} \mathrm{Cl}_{2}, 4.1: 1$ $E: Z$; e) 18, Oxone, $n \mathrm{Bu}_{4} \mathrm{NHSO}_{4}, \mathrm{~K}_{2} \mathrm{CO}_{3}, \mathrm{Na}_{2} \mathrm{~B}_{4} \mathrm{O}_{7}$ buffer, $\mathrm{DMM} / \mathrm{MeCN}, 0^{\circ}, 90 \%$ over 2 steps, 2.7:1 overall dr; f) TBAF, THF, $98 \%$. 


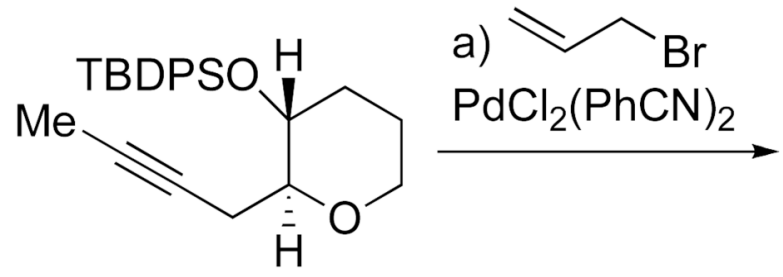

32<smiles>[R][C@]1([2H])CCCO[C@@H]1C/C(CC=C)=C(/C)Br</smiles>

\section{3 (R=TBDPS) \\ $47 \%$ \\ undesired}

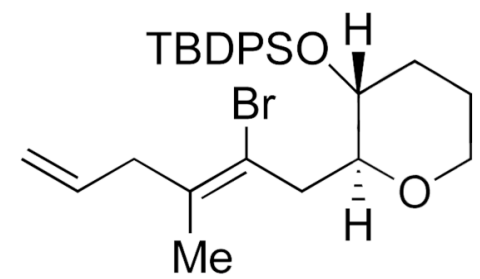

34

$22 \%$

desired

Scheme 10.

Bromoallylation of internal alkyne 32 a) allyl bromide, $\mathrm{PdCl}_{2}(\mathrm{PhCN})_{2}, \mathrm{NaHCO}_{3}, \mathrm{THF}$, 69\%, 2.2:1 33:34 regioselectivity. 
<smiles>C#CC[C@H]1OCCC[C@H]1O[R5](C)(F)F</smiles>

26

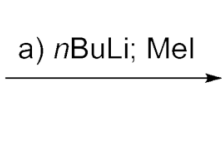

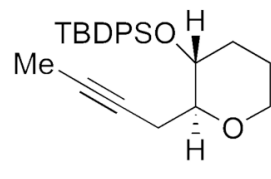

32

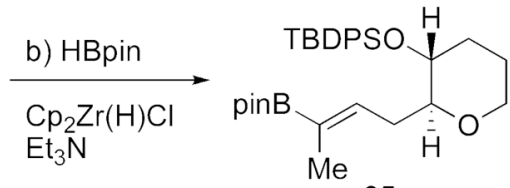

35

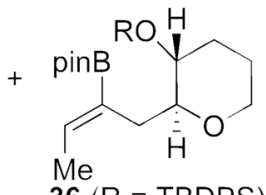

$36(R=T B D P S)$

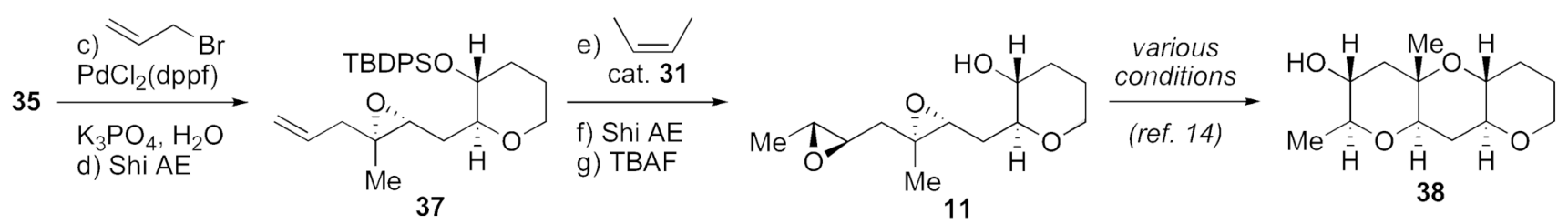

Scheme 11.

Synthesis of diepoxy alcohol 11. a) $n \mathrm{BuLi}$, THF; MeI, 99\%; b) $\mathrm{HBpin}, \mathrm{Cp}_{2} \mathrm{Zr}(\mathrm{H}) \mathrm{Cl}, \mathrm{Et}_{3} \mathrm{~N}, 60^{\circ}$, $44 \%$ (2.0:1 mixture of regiosiomers 35 and 36, 60\% brsm); c) allyl bromide, $\mathrm{PdCl}_{2}$ (dppf), $\mathrm{K}_{3} \mathrm{PO}_{4}, \mathrm{H}_{2} \mathrm{O}$, THF; d) 18, Oxone, $n \mathrm{Bu}_{4} \mathrm{NHSO}_{4}, \mathrm{~K}_{2} \mathrm{CO}_{3}, \mathrm{Na}_{2} \mathrm{~B}_{4} \mathrm{O}_{7}$ buffer, DMM/MeCN, $0^{\circ}$, $53 \%$ over 2 steps, $3: 1 \mathrm{dr}$; e) cis-2-butene, catalyst $31, \mathrm{CH}_{2} \mathrm{Cl}_{2}, 4.2: 1 \mathrm{E:Z}$; f) 18, Oxone,

$n \mathrm{Bu}_{4} \mathrm{NHSO}_{4}, \mathrm{~K}_{2} \mathrm{CO}_{3}, \mathrm{Na}_{2} \mathrm{~B}_{4} \mathrm{O}_{7}$ buffer, DMM/MeCN, $0^{\circ}, 85 \%$ over 2 steps, $1.5: 1$ overall dr; g) TBAF, THF, $95 \%$. 

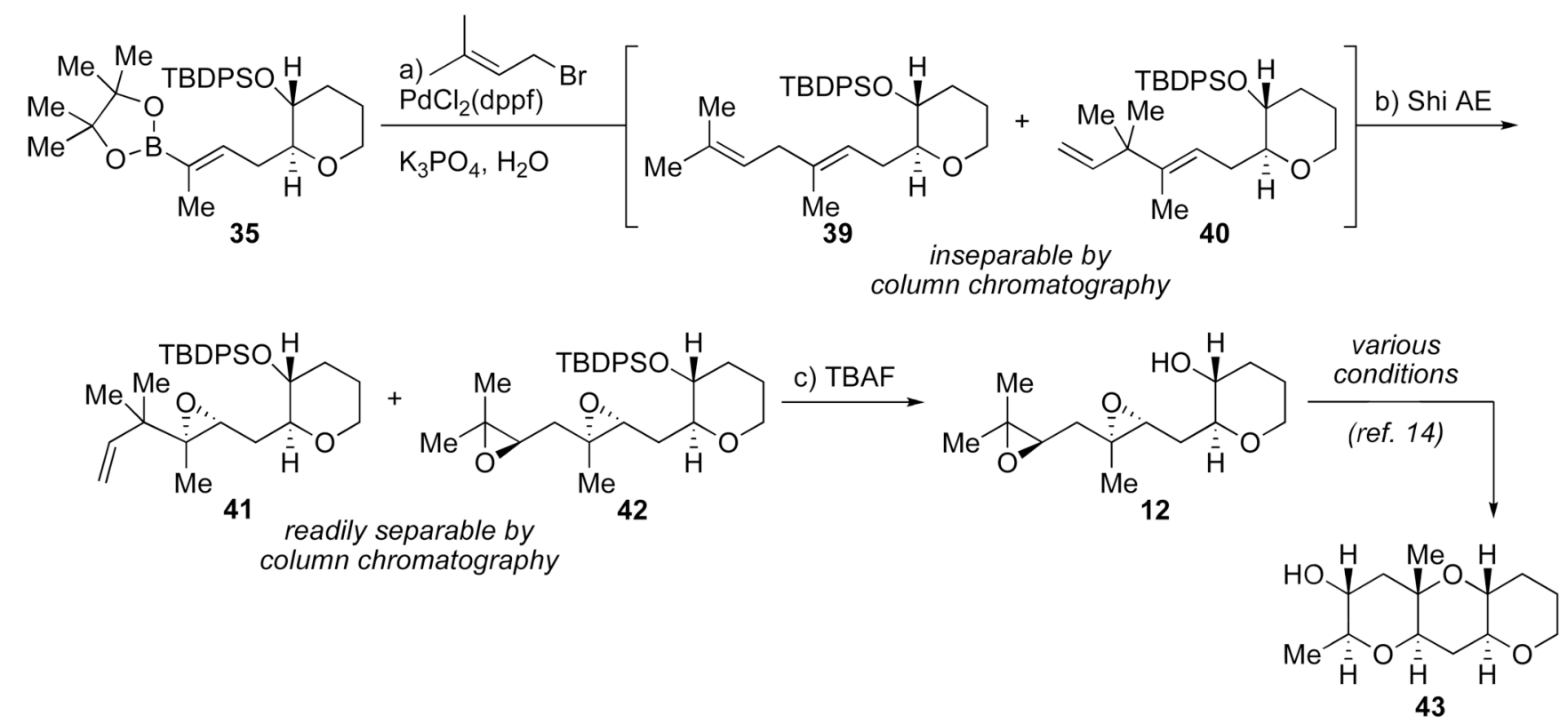

Scheme 12.

Synthesis of diepoxy alcohol 12 a) prenyl bromide, $\mathrm{PdCl}_{2}$ (dppf), $\mathrm{K}_{3} \mathrm{PO}_{4}, \mathrm{H}_{2} \mathrm{O}$, THF, 75\%, 2.5:1 39:40; b) 18, Oxone, $n \mathrm{Bu}_{4} \mathrm{NHSO}_{4}, \mathrm{~K}_{2} \mathrm{CO}_{3}, \mathrm{Na}_{2} \mathrm{~B}_{4} \mathrm{O}_{7}$ buffer, DMM/MeCN, $0^{\circ}, 65 \%$ (yield of $\mathbf{4 2}$ based on 39), 3.5:1 dr; c) TBAF, THF, 92\%. 